Article

\title{
Analysis of Site-Specific Methylation of Tumor-Related Genes in Head and Neck Cancer: Potential Utility as Biomarkers for Prognosis
}

\author{
Kiyoshi Misawa * (D), Daiki Mochizuki, Atsushi Imai, Masato Mima, Yuki Misawa \\ and Hiroyuki Mineta \\ Department of Otolaryngology/Head and Neck Surgery, Hamamatsu University School of Medicine, \\ Shizuoka 431-3192, Japan; daiki_m525@yahoo.co.jp (D.M.); imaimimi@yahoo.co.jp (A.I.); \\ tendoon@gmail.com (M.M.); mswyuki@abox3.so-net.ne.jp (Y.M.); mineta@hama-med.ac.jp (H.M.) \\ * Correspondence: kiyoshim@hama-med.ac.jp; Tel.: +81-53-435-2252; Fax: +81-53-435-2253
}

Received: 26 December 2017; Accepted: 19 January 2018; Published: 22 January 2018

\begin{abstract}
Clarifying the epigenetic regulation of tumor-related genes (TRGs) can provide insights into the mechanisms of tumorigenesis and the risk for disease recurrence in HPV-negative head and neck cancers, originating in the hypopharynx, larynx, and oral cavity. We analyzed the methylation status of the promoters of 30 TRGs in 178 HPV-negative head and neck cancer patients using a quantitative methylation-specific PCR. Promoter methylation was correlated with various clinical characteristics and patient survival. The mean number of methylated TRGs was 14.2 (range, 2-25). In the multivariate Cox proportional hazards analysis, the methylation of COL1A2 and VEGFR1 was associated with poor survival for hypopharyngeal cancer, with hazard ratios: 3.19; $p=0.009$ and 3.07; $p=0.014$, respectively. The methylation of $p 16$ and COL1A2 were independent prognostic factors for poor survival in laryngeal cancer (hazard ratio: $4.55 ; p=0.013$ and 3.12; $p=0.035$, respectively). In patients with oral cancer, the methylation of TAC1 and SSTR1 best correlated with poor survival (hazard ratio: $4.29 ; p=0.005$ and $5.38 ; p=0.029$, respectively). Our findings suggest that methylation status of TRGs could serve as important site-specific biomarkers for prediction of clinical outcomes in patients with HPV-negative head and neck cancer.
\end{abstract}

Keywords: epigenetic regulation; cancer metastasis; tumor-related genes; head and neck cancer; site-specific analysis

\section{Introduction}

Head and neck squamous cell carcinoma (HNSCC) is a disease with a high incidence and an anatomically heterogeneous group of solid tumors affecting mainly the oral cavity, pharynx (naso-, oro-, and hypopharynx) and larynx [1]. Major risk factors for HNSCC include sex, tobacco smoking, alcohol consumption, and an oncovirus infection [2]. In recent decades, the overall incidence of HNSCC has been declining in the developed world due to a reduction in the consumption of tobacco. However, there is a concomitant increase in the incidence of oropharyngeal cancer as a result of human papillomavirus (HPV) infection [3,4]. Additionally, HPV-related tumors more frequently arise in the oropharynx, whereas HPV-negative tumors are more common in the hypopharynx, larynx, or oral cavity [5].

Interestingly, HPV-related HNSCC is a distinct clinical entity, with a significantly improved treatment response and survival rates in comparison to HPV-negative HNSCC [6]. In general, the 5-year overall survival for HPV-negative HNSCC is around 50\%, while that for HPV-related HNSCC patients is around $80 \%[7,8]$. The biological mechanisms underlying the different outcomes in HPV-negative versus HPV-related HNSCC remain poorly understood. It is, therefore, critically important to 
find biomarkers for HPV-negative HNSCC in order to facilitate patient stratification and improve treatment outcomes.

Aberrant promoter methylation is considered a major mechanism underlying the inactivation of tumor-related genes (TRGs). Notably, the methylation profile of gene promoters is different for each type of tumor, allowing the identification of patterns of tumor-specific hypermethylation [9]. Global DNA methylation profiling has revealed that HPV-related HNSCC is a unique molecular entity that exhibits hypermethylation compared to HPV-negative tumors [10-12]. It is important to keep in mind that the molecular spectrum of HNSCC reflects strong influences of what appear to be significantly different tumor microenvironments [12]. Therefore, the development of an integrated analysis method, applicable to various tumor types, is necessary to understand the correlation between a primary tumor site and tumor-specific characteristics.

The aim of this study was to determine the methylation status of TRGs to evaluate their clinical significance as prognostic biomarkers for survival and risk for recurrence in HPV-negative HNSCC. In an attempt to determine if these DNA methylation events are specific to anatomical sites, we have evaluated and compared the methylation changes originating in different anatomical sites (hypopharynx, larynx, and oral cavity). This site-specific analysis may serve as a valuable resource to determine biomarkers for prediction of clinical outcomes in patients with HPV-negative HNSCC.

\section{Results}

\subsection{Characteristics of Patients}

The clinicopathological data of the 178 HNSCC patients included in the study are summarized in Table 1. The study population comprised of $153(86 \%)$ men and $25(14 \%)$ women with an age range of 32-92 years (mean \pm SD.: $65.8 \pm 11.2$ years). While $61(34 \%)$ patients had hypopharyngeal cancer, $49(28 \%)$ had laryngeal cancer, and $68(38 \%)$ had oral cavity cancer in the head and neck region. The rates of smoking and alcohol drinking were both $75 \%$. Most patients $(75 \%)$ had an advanced stage disease (III/IV) at diagnosis, and positive recurrence events were noted in 67 cases (38\%) (Table 1).

Table 1. Clinicopathological data of head and neck squamous cell carcinoma (HNSCC) patients under study.

\begin{tabular}{ccccc}
\hline $\begin{array}{c}\text { Patient and Tumor } \\
\text { Characteristics }\end{array}$ & $\begin{array}{c}\text { Full Panel } \\
(\boldsymbol{n}=\mathbf{1 7 8})\end{array}$ & $\begin{array}{c}\text { Hypopharynx } \\
(\boldsymbol{n}=\mathbf{6 1})\end{array}$ & $\begin{array}{c}\text { Larynx } \\
(\boldsymbol{n}=\mathbf{4 9})\end{array}$ & $\begin{array}{c}\text { Oral Cavity } \\
(\boldsymbol{n}=\mathbf{6 8})\end{array}$ \\
\hline Age & $65.8 \pm 11.2$ & $66.7 \pm 10.2$ & $68.9 \pm 8.3$ & $62.9 \pm 13.1$ \\
Mean \pm S.D. & $153(86 \%)$ & $54(89 \%)$ & $47(96 \%)$ & $52(76 \%)$ \\
Gender & $25(14 \%)$ & $7(11 \%)$ & $2(4 \%)$ & $16(24 \%)$ \\
Male & & & & \\
Female & $135(76 \%)$ & $51(84 \%)$ & $40(81 \%)$ & $44(65 \%)$ \\
Alcohol exposure & $43(24 \%)$ & $10(16 \%)$ & $9(18 \%)$ & $24(35 \%)$ \\
Ever & $124(70 \%)$ & $46(75 \%)$ & $35(71 \%)$ & $43(63 \%)$ \\
Never & $9(5 \%)$ & $3(5 \%)$ & $2(4 \%)$ & $4(6 \%)$ \\
Smoking status & $45(25 \%)$ & $12(20 \%)$ & $12(25 \%)$ & $21(31 \%)$ \\
Smoker (>1 pack/20 years) & $16(9 \%)$ & $1(2 \%)$ & $4(8 \%)$ & $11(16 \%)$ \\
Smoker (<1 pack/20 years) & $62(35 \%)$ & $21(34 \%)$ & $7(14 \%)$ & $34(50 \%)$ \\
Non-smoker & $19(31 \%)$ & $16(33 \%)$ & $5(7 \%)$ \\
Tumor size & $60(22 \%)$ & $20(33 \%)$ & $22(45 \%)$ & $18(27 \%)$ \\
T1 & $60(34 \%)$ & & & \\
T2 & $81(46 \%)$ & $18(30 \%)$ & $24(49 \%)$ & $39(57 \%)$ \\
T3 & $97(54 \%)$ & $43(70 \%)$ & $25(51 \%)$ & $29(43 \%)$ \\
T4 & & &
\end{tabular}


Table 1. Cont.

\begin{tabular}{ccccc}
\hline $\begin{array}{c}\text { Patient and Tumor } \\
\text { Characteristics }\end{array}$ & $\begin{array}{c}\text { Full Panel } \\
(\boldsymbol{n}=\mathbf{1 7 8})\end{array}$ & $\begin{array}{c}\text { Hypopharynx } \\
(\boldsymbol{n}=\mathbf{6 1 )})\end{array}$ & $\begin{array}{c}\text { Larynx } \\
(\boldsymbol{n}=\mathbf{4 9 )}\end{array}$ & $\begin{array}{c}\text { Oral Cavity } \\
(\boldsymbol{n}=\mathbf{6 8})\end{array}$ \\
\hline Stage & & & & \\
I & $14(8 \%)$ & $0(0 \%)$ & $4(8 \%)$ & $10(15 \%)$ \\
II & $32(18 \%)$ & $9(14 \%)$ & $3(6 \%)$ & $20(29 \%)$ \\
III & $37(21 \%)$ & $16(26 \%)$ & $12(24 \%)$ & $9(13 \%)$ \\
IV & $95(53 \%)$ & $36(59 \%)$ & $30(61 \%)$ & $29(43 \%)$ \\
Recurrence events & $67(38 \%)$ & $25(41 \%)$ & $20(41 \%)$ & $22(32 \%)$ \\
Positive & $111(62 \%)$ & $36(59 \%)$ & $29(59 \%)$ & $46(68 \%)$ \\
Negative & & &
\end{tabular}

\subsection{Analysis of Methylation Status of Tumor-Related Genes}

The frequencies of the promoter hypermethylation of the 30 genes are shown in Figure 1 . The mean number of methylated genes in the full panel was 14.3 (range, 2-25). The overall frequencies of promoter methylation indicated that five genes (SST, SSTR1, HCRTR2, NPFFR1, and NPFFR2) were frequently methylated (greater than $70 \%$ ), while three genes (GAL, NPY, and CDH13) were less frequently methylated (less than $30 \%$ ). We also performed detailed stratified analyses to determine the distributions of methylation status based on the original cancer site. This analysis revealed that methylation frequencies of SST, SSTR1, HCRTR2, NPFFR1, and NPFFR2 genes were greater than $70 \%$ in the hypopharynx, larynx, and oral cavity. Notably, the less frequently methylated genes (less than $30 \%$ ) were as follows: CDH13, p16, MGMT, GAL, NPY, GALR2, and VEGFR3 for hypopharyngeal cancers; CDH13, p16, RASSF1A, GAL, NPY, and NPY1R for laryngeal cancers; and CDH13 and GAL for oral cavity cancers (Figure 1). The methylation status of the 30 tumor-related gene promoters was determined in an additional 516 HNSCC samples and 50 normal samples. The average $\beta$ values for $p 16$, COAL1A2, DAPK, CCBE1, DCC, SALL3, NPY, TAC1, SST, GALR1, GALR2, NPY1R, NPY2R, NPY4R, NPY5R, TACR1, HCRTR1, HCRTR2, SSTR1, NPDDR1, NPFFR2, VEGFR1, VEGFR2, and VEGFR3 methylation were significantly higher in the HNSCC samples than in the normal samples $(p<0.05)$. Methylation of the CDH13, MGMT, CDH1, RASSF1A, GAL, and HCRT promoters was not associated between HNSCC and normal control group. (Figure S1).

\subsection{Correlation Between Gene Methylation and the Original Tumor Site}

Table 2 shows the correlation between the methylation status of TRGs and the original tumor site. Methylation of the $p 16$ gene had a significantly higher frequency in oral cavity cancers when compared to hypopharyngeal and laryngeal cancers ( $p<0.001$ and $p=0.006$, respectively). Methylation of the GAL gene had a significantly lower frequency in hypopharyngeal cancers when compared to laryngeal cancers and oral cavity cancers $(p=0.035$ and $p=0.007$, respectively). Patients with oral cavity cancers showed a significantly higher NPY methylation in comparison to patients with hypopharyngeal cancers $(p=0.003)$. We also found significantly lower methylation of the HCRT gene in laryngeal cancers compared to hypopharyngeal cancers and oral cavity cancers $(p=0.016$ and $p=0.025$, respectively). The GALR2 gene methylation was significantly lower in hypopharyngeal cancers compared to laryngeal cancers and oral cavity cancers $(p=0.026$ and $p<0.001$, respectively) (Table 2). 


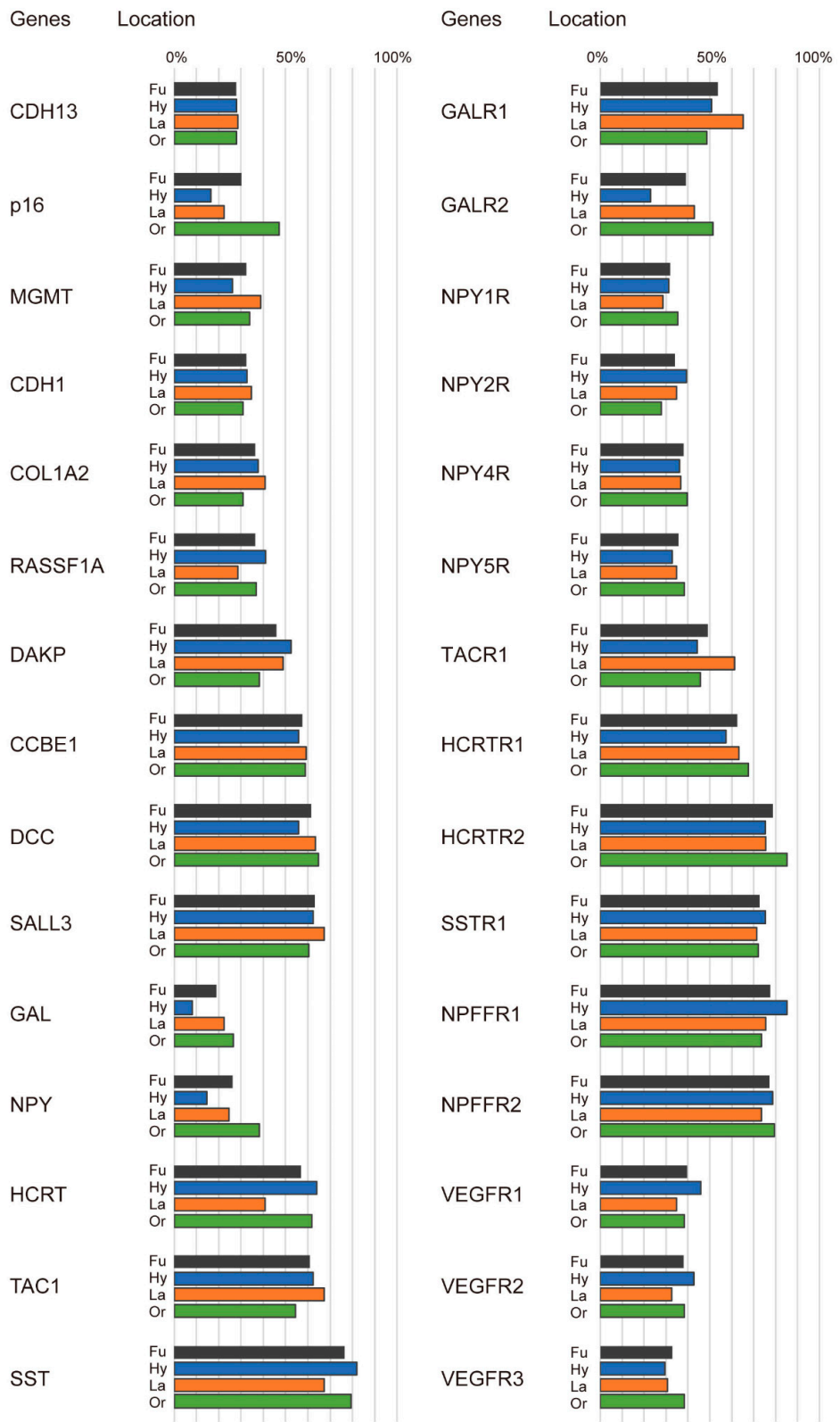

Figure 1. Summary of hypermethylation of tumor-related gene (TRG) promoters in HNSCC samples. Shown here are the methylation frequencies (\%) of 30 TRGs in the cohort. Grey bars: Fu: full panel; blue bars: Hy: hypopharyngeal cancer; orange bars: La: laryngeal cancer; green bars: Or: oral cavity cancer.

Table 2. Correlation between tumor sites and methylation status.

\begin{tabular}{|c|c|c|c|c|c|c|c|}
\hline \multirow{2}{*}{ Genes } & \multirow{2}{*}{$\begin{array}{l}\text { Methylation } \\
\text { Status }\end{array}$} & \multirow{2}{*}{$\begin{array}{l}\text { Hypopharynx } \\
(\mathbf{N}=61)\end{array}$} & \multirow{2}{*}{$\begin{array}{l}\text { Larynx } \\
(N=49)\end{array}$} & \multirow{2}{*}{$\begin{array}{l}\text { Oral Cavity } \\
\quad(N=68)\end{array}$} & \multicolumn{3}{|c|}{$p$-Values $x$} \\
\hline & & & & & Hy vs. La & La vs. Or & Hy vs. Or \\
\hline \multirow[t]{2}{*}{ CDH13 } & Methylated & 17 & 14 & 19 & & & \\
\hline & Unmethylated & 44 & 35 & 49 & 0.935 & 0.94 & 0.993 \\
\hline \multirow[t]{2}{*}{$p 16$} & Methylated & 10 & 11 & 32 & & & \\
\hline & Unmethylated & 51 & 38 & 36 & 0.422 & $0.006^{*}$ & $0.0002 *$ \\
\hline \multirow[t]{2}{*}{ MGMT } & Methylated & 16 & 19 & 23 & & & \\
\hline & Unmethylated & 45 & 30 & 45 & 0.16 & 0.582 & 0.348 \\
\hline \multirow[t]{2}{*}{$\mathrm{CDH1}$} & Methylated & 20 & 17 & 21 & & & \\
\hline & Unmethylated & 41 & 32 & 47 & 0.833 & 0.664 & 0.817 \\
\hline
\end{tabular}


Table 2. Cont.

\begin{tabular}{|c|c|c|c|c|c|c|c|}
\hline \multirow{2}{*}{ Genes } & \multirow{2}{*}{$\begin{array}{l}\text { Methylation } \\
\text { Status }\end{array}$} & \multirow{2}{*}{$\begin{array}{c}\text { Hypopharynx } \\
(\mathrm{N}=61)\end{array}$} & \multirow{2}{*}{$\begin{array}{l}\text { Larynx } \\
(N=49)\end{array}$} & \multirow{2}{*}{$\begin{array}{l}\text { Oral Cavity } \\
\quad(N=68)\end{array}$} & \multicolumn{3}{|c|}{$p$-Values $X$} \\
\hline & & & & & Hy vs. La & La vs. Or & Hy vs. Or \\
\hline \multirow[t]{2}{*}{ COL1A2 } & Methylated & 23 & 20 & 21 & & & \\
\hline & Unmethylated & 38 & 29 & 47 & 0.74 & 0.267 & 0.414 \\
\hline \multirow[t]{2}{*}{ RASSF1A } & Methylated & 25 & 14 & 25 & & & \\
\hline & Unmethylated & 36 & 35 & 43 & 0.176 & 0.354 & 0.623 \\
\hline \multirow[t]{2}{*}{$D A P K$} & Methylated & 32 & 24 & 26 & & & \\
\hline & Unmethylated & 29 & 25 & 42 & 0.717 & 0.246 & 0.105 \\
\hline \multirow[t]{2}{*}{ CCBE1 } & Methylated & 34 & 29 & 40 & & & \\
\hline & Unmethylated & 27 & 20 & 28 & 0.717 & 0.969 & 0.723 \\
\hline \multirow[t]{2}{*}{$D C C$} & Methylated & 34 & 31 & 44 & & & \\
\hline & Unmethylated & 27 & 18 & 24 & 0.425 & 0.873 & 0.298 \\
\hline \multirow[t]{2}{*}{$S A L L 3$} & Methylated & 38 & 33 & 41 & & & \\
\hline & Unmethylated & 23 & 16 & 27 & 0.582 & 0.435 & 0.813 \\
\hline \multirow[t]{2}{*}{$G A L$} & Methylated & 5 & 11 & 18 & & & \\
\hline & Unmethylated & 56 & 38 & 50 & $0.035 *$ & 0.619 & $0.007 *$ \\
\hline \multirow[t]{2}{*}{$N P Y$} & Methylated & 9 & 12 & 26 & & & \\
\hline & Unmethylated & 52 & 37 & 42 & 0.197 & 0.117 & 0.003 * \\
\hline \multirow[t]{2}{*}{ HCRT } & Methylated & 39 & 20 & 42 & & & \\
\hline & Unmethylated & 22 & 29 & 26 & $0.016 *$ & $0.025 *$ & 0.799 \\
\hline \multirow[t]{2}{*}{ TAC1 } & Methylated & 38 & 33 & 37 & & & \\
\hline & Unmethylated & 23 & 16 & 31 & 0.582 & 0.159 & 0.365 \\
\hline \multirow[t]{2}{*}{ SST } & Methylated & 50 & 33 & 54 & & & \\
\hline & Unmethylated & 11 & 16 & 14 & 0.077 & 0.14 & 0.714 \\
\hline \multirow[t]{2}{*}{ GALR1 } & Methylated & 31 & 32 & 33 & & & \\
\hline & Unmethylated & 30 & 17 & 35 & 0.127 & 0.072 & 0.795 \\
\hline GALR2 & Methylated & 14 & 21 & 35 & & & \\
\hline & Unmethylated & 47 & 28 & 33 & $0.026^{*}$ & 0.357 & $p<0.001 *$ \\
\hline NPY1R & Methylated & 19 & 14 & 24 & & & \\
\hline & Unmethylated & 42 & 35 & 44 & 0.769 & 0.444 & 0.618 \\
\hline$N P Y 2 R$ & Methylated & 24 & 17 & 19 & & & \\
\hline & Unmethylated & 37 & 32 & 49 & 0.616 & 0.435 & 0.17 \\
\hline NPY4R & Methylated & 22 & 18 & 27 & & & \\
\hline & Unmethylated & 39 & 31 & 41 & 0.942 & 0.744 & 0.671 \\
\hline NPY5R & Methylated & 20 & 17 & 26 & & & \\
\hline & Unmethylated & 41 & 32 & 42 & 0.833 & 0.695 & 0.519 \\
\hline TACR1 & Methylated & 27 & 30 & 31 & & & \\
\hline & Unmethylated & 34 & 19 & 37 & 0.077 & 0.095 & 0.88 \\
\hline HCRTR1 & Methylated & 35 & 31 & 46 & & & \\
\hline & Unmethylated & 26 & 18 & 22 & 0.531 & 0.622 & 0.228 \\
\hline HCRTR2 & Methylated & 46 & 37 & 58 & & & \\
\hline & Unmethylated & 15 & 12 & 10 & 0.99 & 0.181 & 0.156 \\
\hline SSTR1 & Methylated & 46 & 35 & 49 & & & \\
\hline & Unmethylated & 15 & 14 & 19 & 0.638 & 0.94 & 0.666 \\
\hline NPFFR1 & Methylated & 52 & 37 & 50 & & & \\
\hline & Unmethylated & 9 & 12 & 18 & 0.197 & 0.809 & 0.102 \\
\hline NPFFR2 & Methylated & 48 & 36 & 54 & & & \\
\hline & Unmethylated & 13 & 13 & 14 & 0.522 & 0.452 & 0.92 \\
\hline VEGFR1 & Methylated & 28 & 17 & 26 & & & \\
\hline & Unmethylated & 33 & 32 & 42 & 0.235 & 0.695 & 0.378 \\
\hline VEGFR2 & Methylated & 26 & 16 & 26 & & & \\
\hline & Unmethylated & 35 & 33 & 42 & 0.285 & 0.535 & 0.612 \\
\hline VEGFR3 & Methylated & 18 & 15 & 26 & & & \\
\hline & Unmethylated & 43 & 34 & 42 & 0.9 & 0.394 & 0.297 \\
\hline
\end{tabular}

Hy vs. La: Hypopharynx vs. Larynx; La vs. Or: Larynx vs. Oral cavity; Hy vs. Or: Hypopharynx vs. Oral cavity; $x$ Chi square test used to calculate $p$-value. ${ }^{*} p<0.05$ considered statistically significant, the same as below.

\subsection{Correlation Between TRG Methylation and Clinicopathological Assessment}

Methylation index (MI) was defined as the ratio between the number of methylated genes and the total number of tested genes in each sample. The mean differences in MI according to the age of onset, sex, alcohol consumption, smoking habit, tumor size, lymph node status, clinical stage, and recurrence are illustrated in Figure 2. Continuous marker methylation analyses showed no association between 
the MI for the 30 TRGs and any clinical parameters in the full panel of 178 patients (Figure 2A) or just in patients with hypopharyngeal (Figure 2B) and laryngeal cancers (Figure 2C). Notably, we found that the MI was significantly higher in the recurrence-positive cases $(16.7 \pm 5.1)$ compared to the recurrence-negative cases $(13.5 \pm 5.2 ; p=0.017)$ of oral cancers (Figure 2D).

a

Full panel $(n=178)$

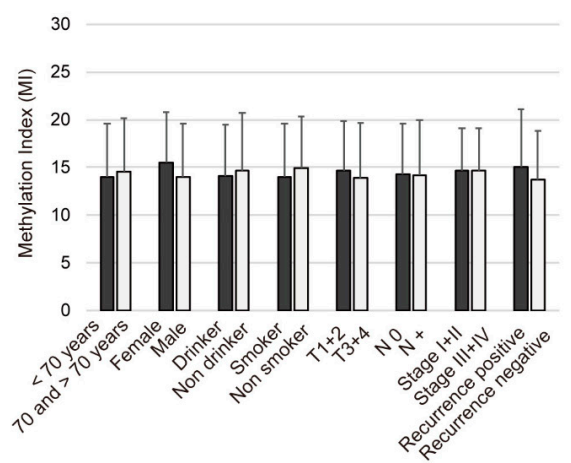

C

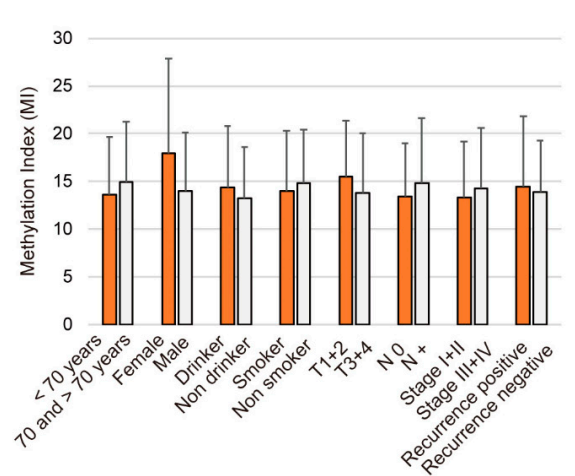

b Hypopharygeal cancer $(n=61)$

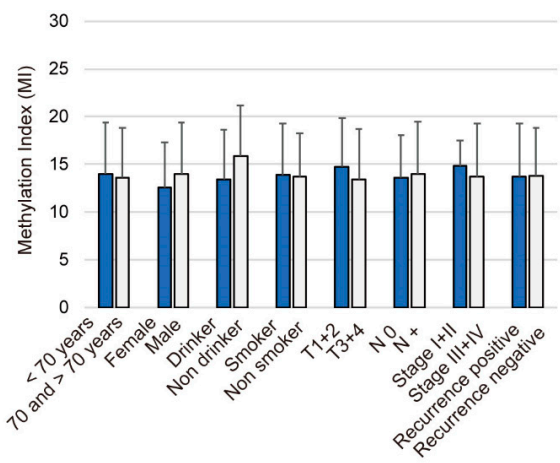

d Oral cancer $(n=68)$

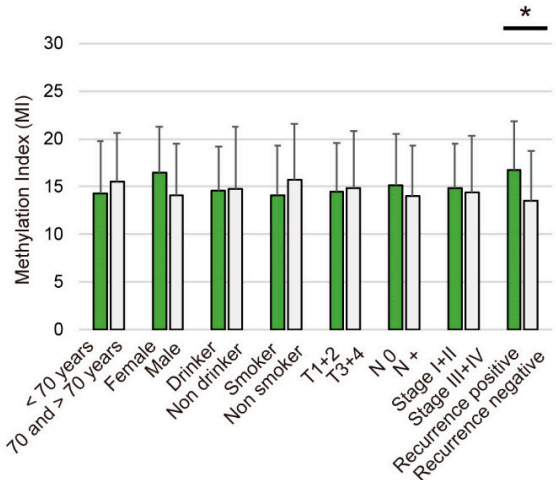

Figure 2. Association between methylation indices (MI) and selected clinical parameters. The mean MI for the various groups was compared using Student's $t$-tests. Shown are the associations between MI and selected epidemiologic and clinical characteristics in (A) full panel; (B) hypopharyngeal cancer; (C) laryngeal cancer; and (D) oral cavity cancer. Statistical comparisons between the groups are represented as a mean with standard deviation. A probability of $<0.05\left({ }^{*} p<0.05\right)$ was considered to represent a statistically significant difference.

\subsection{Associations Between TRGs Methylation and Survival}

The association between methylation and risk of recurrence was estimated via a multivariate analysis using a Cox proportional hazards model adjusted for age ( $\geq 70$ years vs. $<70$ years), sex, alcohol consumption, smoking status, and clinical stage. In patients with hypopharyngeal cancers, methylation of COL1A2 and VEGFR1 promoters correlated positively with recurrence (odds ratio $(\mathrm{OR})=3.19$, 95\% CI: 1.33-7.66, $p=0.009$ and OR $=3.07,95 \%$ CI: 1.25-7.49, $p=0.014$, respectively) (Figure 3A). In patients with laryngeal cancers, methylation of $p 16$ and COL1A2 promoters were associated with poor survival (OR $=4.55,95 \%$ CI: $1.36-15.2, p=0.013$ and OR $=3.12,95 \%$ CI: $1.08-8.99, p=0.035$, respectively). The opposing influences of promoter methylation of CCBE1 and SST showed association with the OR for recurrence (OR $=0.21,95 \%$ CI: 0.07-0.66, $p=0.007$ and OR $=0.29,95 \%$ CI: 0.09-0.90, $p=0.033$, respectively) (Figure $3 \mathrm{~B}$ ). In patients with oral cavity cancers, hypermethylation of DAPK, 
TAC1, GALR1, NPY1R, SSTR1, and VEGFR3 was associated with significantly reduced survival, with hazard ratios of 2.93 (95\% CI: 1.17-7.35), 4.29 (95\% CI: 1.54-11.9), 2.44 (95\% CI: 1.00-5.96), 2.37 (95\% CI: 1.05-5.34), 5.38 (95\% CI: 1.19-24.3), and 2.55 (95\% CI: 1.12-5.78), respectively (Figure 3C).

a Hypopharygeal cancer $(n=61)$

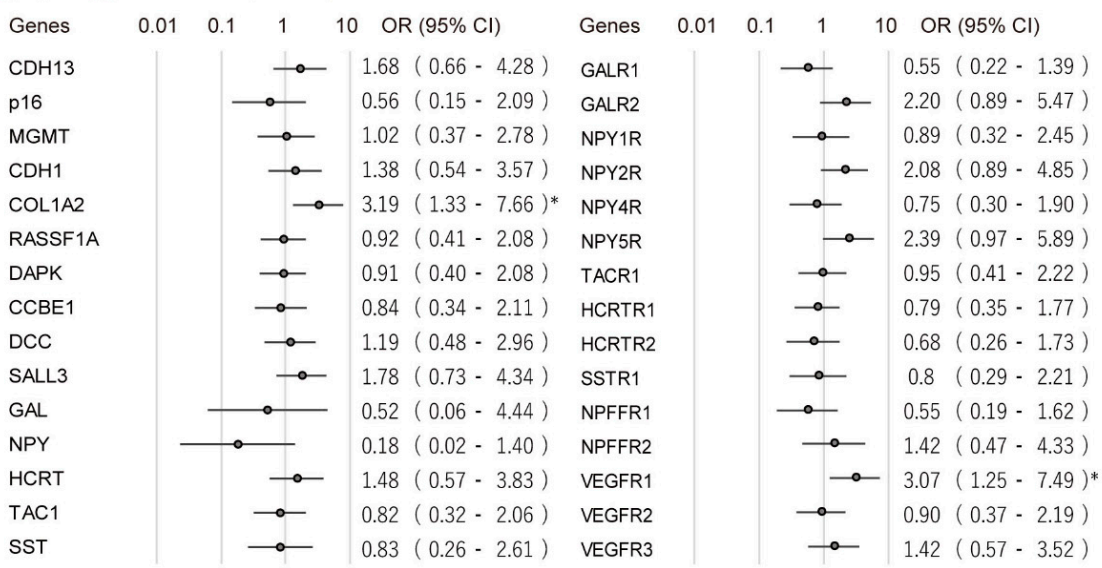

b Laryngeal cancer $(n=49)$

\begin{tabular}{|c|c|c|c|c|c|}
\hline Genes & 0.010 .1 & 100 OR $(95 \% \mathrm{Cl})$ & Genes & 0.010 .1 & OR $(95 \% \mathrm{Cl})$ \\
\hline $\mathrm{CDH} 13$ & $\longrightarrow$ & $0.99(0.24-4.13)$ & GALR1 & & $0.63(0.21-1.89)$ \\
\hline p16 & 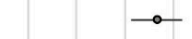 & $4.55(1.36-15.2)^{*}$ & GALR2 & & $1.04(0.39-2.75)$ \\
\hline MGMT & $\multimap$ & $0.69(0.23-2.10)$ & NPY1R & & $1.06(0.28-3.99)$ \\
\hline $\mathrm{CDH} 1$ & & $1.17(0.41-3.32)$ & NPY2R & & $2.25(0.76-6.64)$ \\
\hline COL1A2 & & $3.12(1.08-8.99)^{*}$ & NPY4R & & $1.38(0.37-5.19)$ \\
\hline RASSF1A & & $1.09(0.29-4.06)$ & NPY5R & & $1.52(0.46-5.05)$ \\
\hline DAPK & & $0.87(0.32-2.40)$ & TACR1 & & $0.60(0.21-1.72)$ \\
\hline CCBE1 & & $0.21(0.07-0.66)^{*}$ & HCRTR1 & & $0.44(0.15-1.25)$ \\
\hline DCC & & $1.26(0.44-3.60)$ & HCRTR2 & & $0.46(0.16-1.37)$ \\
\hline SALL3 & & $3.07(0.68-13.7)$ & SSTR1 & & $1.13(0.26-5.02)$ \\
\hline GAL & & $2.19(0.85-5.66)$ & NPFFR1 & & $0.37(0.12-1.10)$ \\
\hline NPY & & $0.37(0.10-1.41)$ & NPFFR2 & & $0.58(0.18-1.90)$ \\
\hline HCRT & -0 & $0.39(0.12-1.33)$ & VEGFR1 & & $1.63(0.48-5.55)$ \\
\hline TAC1 & $\rightarrow$ & $0.83(0.31-2.25)$ & VEGFR2 & & $0.52(0.11-2.46)$ \\
\hline SST & $\multimap$ & $0.29(0.09-0.90)^{*}$ & VEGFR3 & & $2.00(0.66-6.03)$ \\
\hline
\end{tabular}

C Oral cancer $(n=68)$

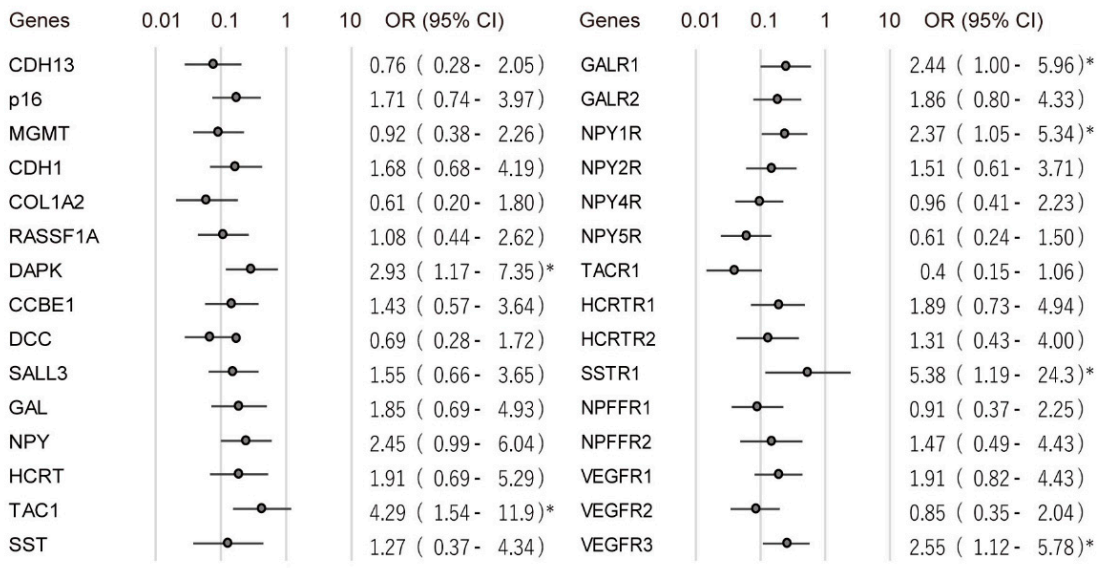

Figure 3. Odds ratios (ORs) for recurrence of cancers. Shown are the ORs of recurrence associated with methylation of different tumor-related genes (TRGs) in (a) hypopharyngeal cancer; (b) laryngeal cancer; and (c) oral cancer. ORs were calculated based on the Cox proportional hazards model, adjusted for age ( $\geq 70$ years vs. $<70$ years), sex, alcohol exposure, smoking status, and tumor stage (I and II vs. III and IV). CI: confidence interval. ${ }^{*} p<0.05$. 


\section{Discussion}

This study reports a real-time PCR analysis of DNA methylation profiles obtained from the genomic DNA of 178 HNSCC tissues derived from cancers originating in three anatomical sites. Overall, we found that aberrant promoter methylation patterns of specific TRGs are indicators of an increased risk of recurrence. Therefore, the development of an integrated analysis method, applicable to various tumor types, is necessary to determine the correlation between the primary tumor site and the tumor-specific characteristics.

Interestingly, we found a strong association between the methylation levels of COL1A2 and disease-free survival (DFS) in hypopharyngeal and laryngeal cancers, but not in oral cavity cancers. COL1A2 is a fibrillar collagen found in most connective tissues and is the main component of the organic part of bones [13]. Hypermethylation of COL1A2 has been described in breast carcinomas [14], melanomas [15], and medulloblastomas [16,17]. The COL1A2 methylation status may, therefore, serve as an important site-specific biomarker for the prediction of clinical outcomes in patients with hypopharyngeal and laryngeal cancers.

In laryngeal cancers, the OR for recurrence is higher when the $p 16$ promoter is methylated versus unmethylated. On the other hand, there is no association between $p 16$ methylation and prognosis in hypopharyngeal and oral cavity cancers. The $p 16$ promoter hypermethylation is a widespread epigenetic alteration, which is known to play a significant role in activating $p 16$ in many tumor types $[9,18,19]$. Although our results were consistent with these reports, there was a discrepancy in the anatomical subtype. The association of HPV-positive oropharyngeal cancer with methylation levels of the $p 16$ promoter regions is still controversial. Nakagawa et al. have reported a very low frequency of p16 promoter region hypermethylation by pyrosequencing. Non-small cell lung cancer patients with hypermethylation of the $p 16$ promoter are at a moderate risk of recurrence and death in all populations considered [20,21]. Our data, plus that of others, therefore suggest that $p 16$ methylation affects tumor behavior and clinical outcomes through interaction with tobacco exposure.

In patients with oral cavity cancers methylation of some genes, including DAPK, NPY, TAC1, GALR1, NPY1R, NPY2R, SSTR1, and VEGFR3 correlated with poor survival. We have carefully reviewed the literature on the association between methylation of TRGs and survival in patients with HNSCC (Table 3) [22-36]. Oral cavity cancer is a multifactorial disease in which chronic alcohol and tobacco use constitute two major risk factors, while chronic inflammation, viral infections, betel quid/areca-nut chewing, and genetic predisposition are supplementary factors that contribute towards its pathogenesis [37]. Chronic inflammation of the oral mucosa is another risk factor that can potentially modify the methylation status of various genes in oral cavity cancer tumors [38]. The occurrence of multiple cytosine-phosphate-guanine (CpG) methylation sites in a panel of TRGs in oral cavity cancer was highly associated with the stage of cancer progression [32]. Recently, it is reported that saliva-derived DNA is a surrogate noninvasive biomarker panel to discriminate healthy controls from patients with HNSCC [39-41]. Therefore, epigenetic alterations may contribute to the etiology of oral carcinogenesis by transcriptional silencing.

Table 3. Published studies of TRG hypermethylation and survival of hypopharyngeal cancer, laryngeal cancer, and oral cavity cancer patients.

\begin{tabular}{ccccccc}
\hline $\begin{array}{c}\text { Study } \\
\text { (Reference.) }\end{array}$ & Year & Country & Cases & Primary Site & Genes Studied & $\begin{array}{c}\text { Significant Association } \\
\text { between Methylation and } \\
\text { Survival * }\end{array}$ \\
\hline $\begin{array}{c}\text { Wei DM [22] } \\
\text { Stephen JK [23] }\end{array}$ & 2015 & China & 53 & hypopharyx & DAPK & Worse survival $(p=0.045)$ \\
Shen Z [24] & 2016 & China & 79 & $\begin{array}{c}\text { larynx } \\
\text { larynx }\end{array}$ & $\begin{array}{c}\text { HIC1, ESR1 } \\
\text { miR-34a }\end{array}$ & HIC1 worse survival $(p<0.01)$ \\
Shen Z [25] & 2017 & China & 91 & larynx & Claudin-11 & Worse survival $(p=0.023)$ \\
Shen Z [26] & 2017 & China & 93 & larynx & SHISA3 & Worse survival $(p=0.007)$ \\
& & & & & & $95 \%$ CI: $1.024-7.177 ; p=0.047)$ \\
\hline
\end{tabular}


Table 3. Cont

\begin{tabular}{|c|c|c|c|c|c|c|}
\hline $\begin{array}{c}\text { Study } \\
\text { (Reference.) }\end{array}$ & Year & Country & Cases & Primary Site & Genes Studied & $\begin{array}{c}\text { Significant Association } \\
\text { between Methylation and } \\
\text { Survival * }\end{array}$ \\
\hline Ogi K [27] & 2002 & Japan & 96 & oral cavity & $\begin{array}{c}\text { MINT31, MINT1, } \\
\text { MINT2, MINT27, p16, } \\
\text { p15, p14, DCC, DAPK }\end{array}$ & $\begin{array}{c}\text { MINT31 worse survival } \\
(\mathrm{HR}=3.79 ; 95 \% \text { CI: } 1.58-9.10 ; \\
p<0.001)\end{array}$ \\
\hline Long NK [28] & 2008 & Japan & 40 & oral cavity & RECK & Worse survival $(p=0.023)$ \\
\hline Taioli E [29] & 2009 & USA & 88 & oral cavity & $\begin{array}{c}M G M T, C D K N 2 A, \\
\text { RASSF1 }\end{array}$ & $\begin{array}{c}\text { MGMT worse survival } \\
(\mathrm{HR}=3.49,95 \% \text { CI: } 1.62-7.52 ; \\
p=0.001)\end{array}$ \\
\hline Supić G [30] & 2009 & Serbia & 77 & oral cavity & $\begin{array}{c}\text { CDH1, DAPK, MGMT, } \\
\text { WRN, APC }\end{array}$ & $C D H 1$ worse survival $(p=0.024)$ \\
\hline Huang KH [31] & 2009 & Taiwan & 166 & oral cavity & $\begin{array}{l}\text { RASSF1A, HIN-1, } \\
\text { RASSF2A, PTEN }\end{array}$ & $\begin{array}{c}\text { RASSF1A worse survival } \\
(\mathrm{n}=166 ; \mathrm{HR}=2.09,95 \% \mathrm{CI} \\
1.25-3.50) \\
\text { HIN-1 worse survival }(\mathrm{n}=116 \\
\text { HR }=2.66 ; 95 \% \text { CI: } 1.30-5.45)\end{array}$ \\
\hline Supic G [32] & 2011 & Serbia & 47 & oral cavity & $\begin{array}{l}\text { DAPK, p16, RASSF1A, } \\
\text { APC, CDH1, RUNX3, } \\
\text { WIF1, MGMT, hMLH }\end{array}$ & $\begin{array}{c}\text { DAPK worse survival }(\mathrm{HR}=4.11 \\
95 \% \text { CI: } 1.46-1.56 ; p=0.007)\end{array}$ \\
\hline Dong Y [33] & 2012 & China & 30 & oral cavity & p16 & $p 16$ worse survival $(p=0.021)$ \\
\hline Lin HY [34] & 2013 & Taiwan & 44 & oral cavity & $\begin{array}{c}D A P K, \text { RASSF1A, IRF8, } \\
\text { SFRP1 }\end{array}$ & $\begin{array}{c}\text { DAPK worse survival }(\mathrm{HR}=2.83 \\
95 \% \mathrm{CI}: 1.05-7.63 ; p=0.042)\end{array}$ \\
\hline Yang CM [35] & 2016 & Taiwan & 86 & oral cavity & SOX21-AS1 & $\begin{array}{l}\text { SOX21-AS1 worse survival } \\
\qquad(p=0.002)\end{array}$ \\
\hline Ribeiro IP [36] & 2016 & Portugal & 93 & oral cavity & $\begin{array}{c}\text { GATA5, WT1, MSH6, } \\
\text { PAX5 }\end{array}$ & GATA5 worse survival $(p=0.049)$ \\
\hline
\end{tabular}

Generally, HPV-negative HNSCCs were more broadly distributed among different anatomical sites, compared to the HPV-related tumors, and commonly occurred in the context of heavy alcohol or tobacco use [42]. Despite continuous efforts to identify molecular markers for early detection, and to develop effective treatments, the survival and prognosis of HNSCC patients remain poor [43]. Locoregional recurrence and metastasis are the limiting factors for successful treatments [43]. Profiling DNA methylation is a widely applied tool to identify subtypes of cancers and to predict therapy outcomes [44]. Several studies have been carried out to explore the association between changes in DNA methylation and survival of patients with hypopharynx, larynx, and oral cavity cancers [22-36]. As we proceed towards personalized and precision medicine, it is important to remember that, though the genetic material is identical in every cell, epigenetics introduces high variability within different tissues and cell types and is affected by environmental factors $[45,46]$. Our findings, therefore, suggest that such methylation markers could be used in clinical practice to identify patients who may benefit from adjuvant therapy after an initial surgical treatment. Furthermore, HPV-negative HNSCCs originating in different anatomical sites showed some site-specific DNA methylation events.

\section{Materials and Methods}

\subsection{Tumor Samples}

Primary HNSCC samples $(n=178)$ were obtained from patients during surgery at the Department of Otolaryngology, Hamamatsu University School of Medicine (Hamamatsu, Shizuoka, Japan). All patients provided written informed consent, and the study protocol was approved by the Institutional Review Board of the Hamamatsu University School of Medicine. Clinical information, including age, sex, tumor site, smoking habit, alcohol consumption, tumor size, lymph node status, stage grouping, and recurrence events were all obtained from the patients' clinical records. 


\subsection{Bisulfite Treatment and Quantitative Methylation-Specific PCR (Q-MSP) Analysis}

Genomic DNA was extracted from tumor and normal mucosal tissues using the QIAamp DNA MiniKit (Qiagen, Courtaboeuf, France). DNA was subjected to bisulfite treatment, as described previously [47]. The bisulfite-modified DNA was used as a template for fluorescence-based real-time PCR [48]. The amplifications were performed using a TaKaRa Thermal CyclerDice ${ }^{\mathrm{TM}}$ Real Time System TP800 (TaKaRa, Tokyo, Japan). The Q-MSP primers for methylated DNA were Q-MSP-ACTB-F (5'-TGGTGATGGAGGAGGTTTAGAAGT-3') and Q-MSP-ACTB-R (5'-AACCAATAAAACCTACTCCTCCCTTAA-3'). A standard curve was generated using serial dilutions of universally methylated DNAs (EpiScope ${ }^{\mathrm{TM}}$ Methylated HCT116 gDNA; TaKaRa, Tokyo, Japan). We determined the specificity of these primers using serial dilutions of universally unmethylated DNAs (EpiScope ${ }^{\circledR U n m e t h y l a t e d ~ H C T 116 ~ D K O ~ g D N A ; ~ T a K a R a, ~}$ Tokyo, Japan). The normalized methylation value (NMV) was defined as follows: NMV = (TRGs-S/TRGs-FM)/(ACTB-S/ACTB-FM), where TRGs-S and TRGs-FM represent TRG methylation levels in the sample and universally methylated DNAs, respectively. ACTB-S and ACTB-FM correspond to $b$-actin in the sample and universally methylated DNAs, respectively. To analyze the methylation status of CDH13 [49], p16 [50], MGMT [51], CDH1 [50], COL1A2 [52], RASSF1A [50], DAPK [51], CCBE1 [53], DCC [54], SALL3 [48], GAL [55], NPY [56], HCRT [56], TAC1 [57], SST [58], GALR1 [47], GALR [59], NPY1R [56], NPY2R [56], NPY4R [56], NPY5R [56], TACR1 [57], HCRTR1 [56], HCRTR2 [56], SSTR1 [58], NPFFR1 [56], NPFFR2 [56], VEGFR1 [60], VEGFR2 [60], and VEGFR3 [60] primers, conditions and cutoff values were used as previously described. A list of the primer sequences from the Q-MSP analysis is shown in Table S1. The HPV status was evaluated using the HPV Typing Set (Takara, Tokyo, Japan), a PCR primer set specifically designed to identify HPV genotypes $-16,-18$, $-31,-33,-35,-52$ and -58 in genomic DNA. The PCR HPV Typing Set method was performed according to the manufacturer's protocol.

\subsection{Data Analysis and Statistics}

The Q-MSP results and patient characteristics were compared using Student's $t$-tests. The overall methylation value for individual samples was determined by calculating the methylation index (MI), which was then used to determine the overall methylation rate in the individual samples [59]. The MI for each sample was defined as the ratio of the number of methylated genes to the number of total genes tested (i.e., 30).

For the frequency analysis in the contingency tables, the associations between variables and methylation status were analyzed statistically using the chi-square test. DFS was calculated from the date of the initial treatment to the date of diagnosis of locoregional recurrence or distant metastasis. The prognostic value of the methylation status was assessed by performing multivariate Cox proportional hazards analysis adjusted for age ( $\geq 70$ years versus $<70$ years), sex, alcohol intake, smoking status, and tumor stage (I and II versus III and IV). Differences with $\mathrm{P}<0.05$ were considered significant. All statistical analyses were performed using StatMate IV (ATMS Co. Ltd., Tokyo, Japan).

\subsection{Systematic Literature Review}

A systematic search in the PubMed database using the following terms: methylation AND survival AND hypopharyngeal cancer OR laryngeal cancer OR oral cavity cancers were performed in order to identify studies reporting genes in which the detection of hypermethylation on their promoter region showed a statistically significant association with their use as a biomarker for prognosis (Table 3).

\subsection{Collection of Publicly Available Data from TCGA}

Aberrant DNA methylation data contained in TCGA (available in May 2017) were collected from the MethHC (http://methhc.mbc.nctu.edu.tw/php/index.php) and using the Infinium Human Methylation 450 platform (Illumina, Inc., San Diego, CA, USA) and are expressed as $\beta$-values [61]. 


\section{Conclusions}

In conclusion, high throughput epigenetic screening studies suggest differences in the epigenetic profiles of HPV-related and HPV-negative HNSCC, with the former characterized by hypermethylated genes. Better molecular classification of the head and neck tumors is required to provide prognostic as well as mechanistic information to improve patient care. Future planned studies will include a more diverse patient population and a more comprehensive view of the patient backgrounds and environmental factors.

Supplementary Materials: The following are available online at http:/ /www.mdpi.com/2072-6694/10/1/27/ s1. Figure S1: Methylation status of the 30 TRGs in HNSCC and normal samples in TCGA database. The methylation data for 30 TRGs in HNSCC and normal samples were collected from TCGA database. ${ }^{*} p<0.05$. Table S1: Q-MSP Primer List.

Acknowledgments: This study was funded by a Grant-in-Aid for Scientific Research (No. 16K11228, No. 16K20239, No. 17K11380, No. 17K16903 and No. 17K16904) from the Ministry of Education, Culture, Sports, Science, and Technology of Japan. The authors would like to thank Yuko Mohri for her excellent technical support.

Author Contributions: K.M. and Y.M. conceived and designed the study. K.M. wrote the paper, and K.M., D.M., A.I., M.M., Y.M., and H.M. made final revisions and gave final approval.

Conflicts of Interest: The authors declare no conflict of interest.

\section{References}

1. Arantes, L.M.; de Carvalho, A.C.; Melendez, M.E.; Carvalho, A.L.; Goloni-Bertollo, E.M. Methylation as a biomarker for head and neck cancer. Oral Oncol. 2014, 50, 587-592. [CrossRef] [PubMed]

2. Shaw, R.; Beasley, N. Aetiology and risk factors for head and neck cancer: United Kingdom national multidisciplinary guidelines. J. Laryngol. Otol. 2016, 130, S9-S12. [CrossRef] [PubMed]

3. Hama, T.; Tokumaru, Y.; Fujii, M.; Yane, K.; Okami, K.; Kato, K.; Masuda, M.; Mineta, H.; Nakashima, T.; Sugasawa, M.; et al. Prevalence of human papillomavirus in oropharyngeal cancer: A multicenter study in Japan. Oncology 2014, 87, 173-182. [CrossRef] [PubMed]

4. Chai, R.C.; Lambie, D.; Verma, M.; Punyadeera, C. Current trends in the etiology and diagnosis of HPV-related head and neck cancers. Cancer Med. 2015, 4, 596-607. [CrossRef] [PubMed]

5. Spence, T.; Bruce, J.; Yip, K.W.; Liu, F.F. HPV associated head and neck cancer. Cancers 2016, 8, 75. [CrossRef] [PubMed]

6. Masterson, L.; Moualed, D.; Liu, Z.W.; Howard, J.E.; Dwivedi, R.C.; Tysome, J.R.; Benson, R.; Sterling, J.C.; Sudhoff, H.; Jani, P.; et al. De-escalation treatment protocols for human papillomavirus-associated oropharyngeal squamous cell carcinoma: A systematic review and meta-analysis of current clinical trials. Eur. J. Cancer 2014, 50, 2636-2648. [CrossRef] [PubMed]

7. Ang, K.K.; Harris, J.; Wheeler, R.; Weber, R.; Rosenthal, D.I.; Nguyen-Tan, P.F.; Westra, W.H.; Chung, C.H.; Jordan, R.C.; Lu, C.; et al. Human papillomavirus and survival of patients with oropharyngeal cancer. N. Engl. J. Med. 2010, 363, 24-35. [CrossRef] [PubMed]

8. Gillison, M.L.; Zhang, Q.; Jordan, R.; Xiao, W.; Westra, W.H.; Trotti, A.; Spencer, S.; Harris, J.; Chung, C.H.; Ang, K.K. Tobacco smoking and increased risk of death and progression for patients with p16-positive and p16-negative oropharyngeal cancer. J. Clin. Oncol. 2012, 30, 2102-2111. [CrossRef] [PubMed]

9. Esteller, M.; Corn, P.G.; Baylin, S.B.; Herman, J.G. A gene hypermethylation profile of human cancer. Cancer Res. 2001, 61, 3225-3229. [PubMed]

10. The Cancer Genome Atlas Network. Comprehensive genomic characterization of head and neck squamous cell carcinomas. Nature 2015, 517, 576-582.

11. Kostareli, E.; Holzinger, D.; Bogatyrova, O.; Hielscher, T.; Wichmann, G.; Keck, M.; Lahrmann, B.; Grabe, N.; Flechtenmacher, C.; Schmidt, C.R.; et al. HPV-related methylation signature predicts survival in oropharyngeal squamous cell carcinomas. J. Clin. Investig. 2013, 123, 2488-2501. [CrossRef] [PubMed]

12. Lechner, M.; Fenton, T.; West, J.; Wilson, G.; Feber, A.; Henderson, S.; Thirlwell, C.; Dibra, H.K.; Jay, A.; Butcher, L.; et al. Identification and functional validation of HPV-mediated hypermethylation in head and neck squamous cell carcinoma. Genome Med. 2013, 5, 15. [CrossRef] [PubMed] 
13. Lauvrak, S.U.; Munthe, E.; Kresse, S.H.; Stratford, E.W.; Namlos, H.M.; Meza-Zepeda, L.A.; Myklebost, O. Functional characterisation of osteosarcoma cell lines and identification of mRNAs and miRNAs associated with aggressive cancer phenotypes. Br. J. Cancer 2013, 109, 2228-2236. [CrossRef] [PubMed]

14. Loss, L.A.; Sadanandam, A.; Durinck, S.; Nautiyal, S.; Flaucher, D.; Carlton, V.E.; Moorhead, M.; Lu, Y.; Gray, J.W.; Faham, M.; et al. Prediction of epigenetically regulated genes in breast cancer cell lines. BMC Bioinf. 2010, 11, 305. [CrossRef] [PubMed]

15. Bonazzi, V.F.; Nancarrow, D.J.; Stark, M.S.; Moser, R.J.; Boyle, G.M.; Aoude, L.G.; Schmidt, C.; Hayward, N.K. Cross-platform array screening identifies COL1A2, THBS1, TNFRSF10D and UCHL1 as genes frequently silenced by methylation in melanoma. PLoS ONE 2011, 6, e26121. [CrossRef] [PubMed]

16. Schwalbe, E.C.; Lindsey, J.C.; Straughton, D.; Hogg, T.L.; Cole, M.; Megahed, H.; Ryan, S.L.; Lusher, M.E.; Taylor, M.D.; Gilbertson, R.J.; et al. Rapid diagnosis of medulloblastoma molecular subgroups. Clin. Cancer Res. 2011, 17, 1883-1894. [CrossRef] [PubMed]

17. Anderton, J.A.; Lindsey, J.C.; Lusher, M.E.; Gilbertson, R.J.; Bailey, S.; Ellison, D.W.; Clifford, S.C. Global analysis of the medulloblastoma epigenome identifies disease-subgroup-specific inactivation of COL1A2. Neuro Oncol. 2008, 10, 981-994. [CrossRef] [PubMed]

18. Lv, X.; Ye, G.; Zhang, X.; Huang, T. P16 methylation was associated with the development, age, hepatic viruses infection of hepatocellular carcinoma, and p16 expression had a poor survival: A systematic meta-analysis (PRISMA). Medicine 2017, 96, e8106. [CrossRef] [PubMed]

19. Yu, H.; Yang, L.; Fu, Y.; Gao, M.; Tian, L. Clinicopathological significance of the p16 hypermethylation in multiple myeloma, a systematic review and meta-analysis. Oncotarget 2017, 8, 83270-83279. [CrossRef] [PubMed]

20. Brock, M.V.; Hooker, C.M.; Ota-Machida, E.; Han, Y.; Guo, M.; Ames, S.; Glockner, S.; Piantadosi, S.; Gabrielson, E.; Pridham, G.; et al. DNA methylation markers and early recurrence in stage I lung cancer. N. Engl. J. Med. 2008, 358, 1118-1128. [CrossRef] [PubMed]

21. Lou-Qian, Z.; Rong, Y.; Ming, L.; Xin, Y.; Feng, J.; Lin, X. The prognostic value of epigenetic silencing of p16 gene in NSCLC patients: A systematic review and meta-analysis. PLoS ONE 2013, 8, e54970. [CrossRef] [PubMed]

22. Wei, D.M.; Liu, D.Y.; Lei, D.P.; Jin, T.; Wang, J.; Pan, X.L. Aberrant methylation and expression of DAPK1 in human hypopharyngeal squamous cell carcinoma. Acta Otolaryngol. 2015, 135, 70-78. [CrossRef] [PubMed]

23. Stephen, J.K.; Chen, K.M.; Shah, V.; Havard, S.; Kapke, A.; Lu, M.; Benninger, M.S.; Worsham, M.J. DNA hypermethylation markers of poor outcome in laryngeal cancer. Clin. Epigenet. 2010, 1, 61-69. [CrossRef] [PubMed]

24. Shen, Z.; Zhou, C.; Li, J.; Ye, D.; Li, Q.; Wang, J.; Cui, X.; Chen, X.; Bao, T.; Duan, S. Promoter hypermethylation of $m i R-34 a$ contributes to the risk, progression, metastasis and poor survival of laryngeal squamous cell carcinoma. Gene 2016, 593, 272-276. [CrossRef] [PubMed]

25. Shen, Z.; Cao, B.; Lin, L.; Zhou, C.; Ye, D.; Qiu, S.; Li, Q.; Cui, X. The clinical signification of claudin-11 promoter hypermethylation for laryngeal squamous cell carcinoma. Med. Sci. Monit. 2017, 23, 3635-3640. [CrossRef] [PubMed]

26. Shen, Z.; Zhou, C.; Li, J.; Ye, D.; Deng, H.; Cao, B.; Hao, W.; Lin, L.; Zhang, Y. SHISA3 promoter methylation is a potential diagnostic and prognostic biomarker for laryngeal squamous cell carcinoma. Biomed. Res. Int. 2017, 2017, 9058749. [CrossRef] [PubMed]

27. Ogi, K.; Toyota, M.; Ohe-Toyota, M.; Tanaka, N.; Noguchi, M.; Sonoda, T.; Kohama, G.; Tokino, T. Aberrant methylation of multiple genes and clinicopathological features in oral squamous cell carcinoma. Clin. Cancer Res. 2002, 8, 3164-3171. [PubMed]

28. Long, N.K.; Kato, K.; Yamashita, T.; Makita, H.; Toida, M.; Hatakeyama, D.; Hara, A.; Mori, H.; Shibata, T. Hypermethylation of the RECK gene predicts poor prognosis in oral squamous cell carcinomas. Oral Oncol. 2008, 44, 1052-1058. [CrossRef] [PubMed]

29. Taioli, E.; Ragin, C.; Wang, X.H.; Chen, J.; Langevin, S.M.; Brown, A.R.; Gollin, S.M.; Garte, S.; Sobol, R.W. Recurrence in oral and pharyngeal cancer is associated with quantitative MGMT promoter methylation. BMC Cancer 2009, 9, 354. [CrossRef] [PubMed]

30. Supic, G.; Kozomara, R.; Brankovic-Magic, M.; Jovic, N.; Magic, Z. Gene hypermethylation in tumor tissue of advanced oral squamous cell carcinoma patients. Oral Oncol. 2009, 45, 1051-1057. [CrossRef] [PubMed] 
31. Huang, K.H.; Huang, S.F.; Chen, I.H.; Liao, C.T.; Wang, H.M.; Hsieh, L.L. Methylation of RASSF1A, RASSF2A, and HIN-1 is associated with poor outcome after radiotherapy, but not surgery, in oral squamous cell carcinoma. Clin. Cancer Res. 2009, 15, 4174-4180. [CrossRef] [PubMed]

32. Supic, G.; Kozomara, R.; Jovic, N.; Zeljic, K.; Magic, Z. Prognostic significance of tumor-related genes hypermethylation detected in cancer-free surgical margins of oral squamous cell carcinomas. Oral Oncol. 2011, 47, 702-708. [CrossRef] [PubMed]

33. Dong, Y.; Wang, J.; Dong, F.; Wang, X.; Zhang, Y. The correlations between alteration of p16 gene and clinicopathological factors and prognosis in squamous cell carcinomas of the buccal mucosa. J. Oral Pathol. Med. 2012, 41, 463-469. [CrossRef] [PubMed]

34. Lin, H.Y.; Huang, T.T.; Lee, M.S.; Hung, S.K.; Lin, R.I.; Tseng, C.E.; Chang, S.M.; Chiou, W.Y.; Hsu, F.C.; Hsu, W.L.; et al. Unexpected close surgical margin in resected buccal cancer: Very close margin and DAPK promoter hypermethylation predict poor clinical outcomes. Oral Oncol. 2013, 49, 336-344. [CrossRef] [PubMed]

35. Yang, C.M.; Wang, T.H.; Chen, H.C.; Li, S.C.; Lee, M.C.; Liou, H.H.; Liu, P.F.; Tseng, Y.K.; Shiue, Y.L.; Ger, L.P.; et al. Aberrant DNA hypermethylation-silenced SOX21-AS1 gene expression and its clinical importance in oral cancer. Clin. Epigenet. 2016, 8, 129. [CrossRef] [PubMed]

36. Ribeiro, I.P.; Caramelo, F.; Marques, F.; Domingues, A.; Mesquita, M.; Barroso, L.; Prazeres, H.; Juliao, M.J.; Baptista, I.P.; Ferreira, A.; et al. WT1, MSH6, GATA5 and PAX5 as epigenetic oral squamous cell carcinoma biomarkers-A short report. Cell. Oncol. 2016, 39, 573-582. [CrossRef] [PubMed]

37. Gasche, J.A.; Goel, A. Epigenetic mechanisms in oral carcinogenesis. Future Oncol. 2012, 8, 1407-1425. [CrossRef] [PubMed]

38. Gasche, J.A.; Hoffmann, J.; Boland, C.R.; Goel, A. Interleukin-6 promotes tumorigenesis by altering DNA methylation in oral cancer cells. Int. J. Cancer 2011, 129, 1053-1063. [CrossRef] [PubMed]

39. Ovchinnikov, D.A.; Cooper, M.A.; Pandit, P.; Coman, W.B.; Cooper-White, J.J.; Keith, P.; Wolvetang, E.J.; Slowey, P.D.; Punyadeera, C. Tumor-suppressor gene promoter hypermethylation in saliva of head and neck cancer patients. Transl. Oncol. 2012, 5, 321-326. [CrossRef] [PubMed]

40. Ovchinnikov, D.A.; Wan, Y.; Coman, W.B.; Pandit, P.; Cooper-White, J.J.; Herman, J.G.; Punyadeera, C. DNA methylation at the novel CpG sites in the promoter of MED15/PCQAP gene as a biomarker for head and neck cancers. Biomark. Insights 2014, 9, 53-60. [CrossRef] [PubMed]

41. Lim, Y.; Wan, Y.; Vagenas, D.; Ovchinnikov, D.A.; Perry, C.F.; Davis, M.J.; Punyadeera, C. Salivary DNA methylation panel to diagnose HPV-positive and HPV-negative head and neck cancers. BMC Cancer 2016, 16, 749. [CrossRef] [PubMed]

42. Network, T.C. Corrigendum: Comprehensive genomic characterization defines human glioblastoma genes and core pathways. Nature 2013, 494, 506. [CrossRef] [PubMed]

43. Echarri, M.J.; Lopez-Martin, A.; Hitt, R. Targeted therapy in locally advanced and recurrent/metastatic head and neck squamous cell carcinoma (LA-R/M HNSCC). Cancers 2016, 8, 27. [CrossRef] [PubMed]

44. Nisa, L.; Aebersold, D.M.; Giger, R.; Caversaccio, M.D.; Borner, U.; Medova, M.; Zimmer, Y. Profiling invasiveness in head and neck cancer: Recent contributions of genomic and transcriptomic approaches. Cancers 2015, 7, 585-597. [CrossRef] [PubMed]

45. Worsham, M.J.; Stephen, J.K.; Chen, K.M.; Havard, S.; Shah, V.; Gardner, G.; Schweitzer, V.G. Delineating an epigenetic continuum in head and neck cancer. Cancer Lett. 2014, 342, 178-184. [CrossRef] [PubMed]

46. Castilho, R.M.; Squarize, C.H.; Almeida, L.O. Epigenetic modifications and head and neck cancer: Implications for tumor progression and resistance to therapy. Int. J. Mol. Sci. 2017, 18, 1506. [CrossRef] [PubMed]

47. Misawa, K.; Ueda, Y.; Kanazawa, T.; Misawa, Y.; Jang, I.; Brenner, J.C.; Ogawa, T.; Takebayashi, S.; Grenman, R.A.; Herman, J.G.; et al. Epigenetic inactivation of galanin receptor 1 in head and neck cancer. Clin. Cancer Res. 2008, 14, 7604-7613. [CrossRef] [PubMed]

48. Misawa, K.; Mochizuki, D.; Imai, A.; Misawa, Y.; Endo, S.; Mima, M.; Kawasaki, H.; Carey, T.E.; Kanazawa, T. Epigenetic silencing of SALL3 is an independent predictor of poor survival in head and neck cancer. Clin. Epigenet. 2017, 9, 64. [CrossRef] [PubMed]

49. Jin, Z.; Cheng, Y.; Olaru, A.; Kan, T.; Yang, J.; Paun, B.; Ito, T.; Hamilton, J.P.; David, S.; Agarwal, R.; et al. Promoter hypermethylation of CDH13 is a common, early event in human esophageal adenocarcinogenesis and correlates with clinical risk factors. Int. J. Cancer 2008, 123, 2331-2336. [CrossRef] [PubMed] 
50. Kristensen, L.S.; Mikeska, T.; Krypuy, M.; Dobrovic, A. Sensitive melting analysis after real time- methylation specific PCR (SMART-MSP): High-throughput and probe-free quantitative DNA methylation detection. Nucleic Acids Res. 2008, 36, e42. [CrossRef] [PubMed]

51. Martone, T.; Gillio-Tos, A.; De Marco, L.; Fiano, V.; Maule, M.; Cavalot, A.; Garzaro, M.; Merletti, F.; Cortesina, G. Association between hypermethylated tumor and paired surgical margins in head and neck squamous cell carcinomas. Clin. Cancer Res. 2007, 13, 5089-5094. [CrossRef] [PubMed]

52. Misawa, K.; Kanazawa, T.; Misawa, Y.; Imai, A.; Endo, S.; Hakamada, K.; Mineta, H. Hypermethylation of collagen $\alpha 2$ (I) gene (col1a2) is an independent predictor of survival in head and neck cancer. Cancer Biomark. 2011, 10, 135-144. [CrossRef] [PubMed]

53. Barton, C.A.; Gloss, B.S.; Qu, W.; Statham, A.L.; Hacker, N.F.; Sutherland, R.L.; Clark, S.J.; O’Brien, P.M. Collagen and calcium-binding EGF domains 1 is frequently inactivated in ovarian cancer by aberrant promoter hypermethylation and modulates cell migration and survival. Br. J. Cancer 2010, 102, 87-96. [CrossRef] [PubMed]

54. Park, H.L.; Kim, M.S.; Yamashita, K.; Westra, W.; Carvalho, A.L.; Lee, J.; Jiang, W.W.; Baek, J.H.; Liu, J.; Osada, M.; et al. DCC promoter hypermethylation in esophageal squamous cell carcinoma. Int. J. Cancer 2008, 122, 2498-2502. [CrossRef] [PubMed]

55. Misawa, K.; Kanazawa, T.; Misawa, Y.; Uehara, T.; Imai, A.; Takahashi, G.; Takebayashi, S.; Cole, A.; Carey, T.E.; Mineta, H. Galanin has tumor suppressor activity and is frequently inactivated by aberrant promoter methylation in head and neck cancer. Transl. Oncol. 2013, 6, 338-346. [CrossRef] [PubMed]

56. Misawa, K.; Imai, A.; Mochizuki, D.; Misawa, Y.; Endo, S.; Hosokawa, S.; Ishikawa, R.; Mima, M.; Shinmura, K.; Kanazawa, T.; et al. Genes encoding neuropeptide receptors are epigenetic markers in patients with head and neck cancer: A site-specific analysis. Oncotarget 2017, 8, 76318-76328. [CrossRef] [PubMed]

57. Misawa, K.; Kanazawa, T.; Misawa, Y.; Imai, A.; Uehara, T.; Mochizuki, D.; Endo, S.; Takahashi, G.; Mineta, H. Frequent promoter hypermethylation of tachykinin-1 and tachykinin receptor type 1 is a potential biomarker for head and neck cancer. J. Cancer Res. Clin. Oncol. 2013, 139, 879-889. [CrossRef] [PubMed]

58. Misawa, K.; Misawa, Y.; Kondo, H.; Mochizuki, D.; Imai, A.; Fukushima, H.; Uehara, T.; Kanazawa, T.; Mineta, $\mathrm{H}$. Aberrant methylation inactivates somatostatin and somatostatin receptor type 1 in head and neck squamous cell carcinoma. PLoS ONE 2015, 10, e0118588. [CrossRef] [PubMed]

59. Misawa, Y.; Misawa, K.; Kanazawa, T.; Uehara, T.; Endo, S.; Mochizuki, D.; Yamatodani, T.; Carey, T.E.; Mineta, $\mathrm{H}$. Tumor suppressor activity and inactivation of galanin receptor type 2 by aberrant promoter methylation in head and neck cancer. Cancer 2014, 120, 205-213. [CrossRef] [PubMed]

60. Misawa, Y.; Misawa, K.; Kawasaki, H.; Imai, A.; Mochizuki, D.; Ishikawa, R.; Endo, S.; Mima, M.; Kanazawa, T.; Iwashita, T.; et al. Evaluation of epigenetic inactivation of vascular endothelial growth factor receptors in head and neck squamous cell carcinoma. Tumor Biol. 2017, 39. [CrossRef] [PubMed]

61. Huang, W.Y.; Hsu, S.D.; Huang, H.Y.; Sun, Y.M.; Chou, C.H.; Weng, S.L.; Huang, H.D. MethHC: A database of DNA methylation and gene expression in human cancer. Nucleic Acids Res. 2015, 43, D856-D861. [CrossRef] [PubMed]

(C) 2018 by the authors. Licensee MDPI, Basel, Switzerland. This article is an open access article distributed under the terms and conditions of the Creative Commons Attribution (CC BY) license (http://creativecommons.org/licenses/by/4.0/). 